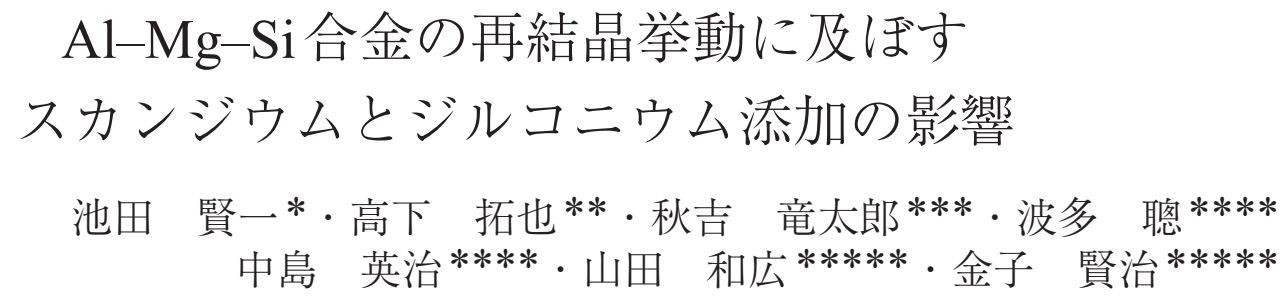

Journal of The Japan Institute of Light Metals, Vol. 66, No. 11 (2016), 609-616

(C) 2016 The Japan Institute of Light Metals

\title{
Effects of Scandium and Zirconium addition on recrystallization behavior of Al-Mg-Si alloy
}

\author{
Ken-ichi IKEDA*, Takuya TAKASHITA**, Ryutaro AKIYOSHI***, Satoshi HATA**** \\ Hideharu NAKASHIMA ${ }^{* * * *}$, Kazuhiro YAMADA***** and Kenji KANEKO*****
}

The effects of thermally stabilized particles in $\mathrm{Al}-\mathrm{Mg}-\mathrm{Si}$ alloy on recrystallization behavior were investigated to obtain fundamental knowledge to control microstructure, texture and mechanical properties of this alloy. In this study, the $\mathrm{Al}-\mathrm{Mg}-\mathrm{Si}-\mathrm{Sc}-\mathrm{Zr}$ alloy was cast, homogenized and hot rolled. Three types of spherical $\mathrm{Al}_{3}(\mathrm{Sc}, \mathrm{Zr})$ particles with $\mathrm{Ll}_{2}$ structure: rod-like incoherent, spherical semi-coherent and spherical incoherent particles were observed in the hot-rolled sample in the Al-Mg-Si-Sc-Zr alloy by using TEM, STEM and EDS. In addition, it was found that all particles have the core-shell structure with the core enriched with Sc and the shell enriched with $\mathrm{Zr}$ atoms by 3D-ET and STEM-EDS. It is considered that these particles are formed during casting, homogenized treatment and hot rolling. The results of crystal orientation distribution of annealed sample after cold rolling indicated that the presence of $\mathrm{Al}_{3}(\mathrm{Sc}, \mathrm{Zr})$ particles may interfere with the recrystallization (the grain growth) until $600^{\circ} \mathrm{C}$. From the comparison with the driving force of primary recrystallization and grain growth, and the pinning force of $\mathrm{Al}_{3}(\mathrm{Sc}, \mathrm{Zr})$ particles, it was suggested that these particles mainly contribute to the suppression of grain growth. The results of in-situ heating SEM/EBSD analysis of cold rolled Al-Mg-Si-Sc-Zr alloy supported the suggestion.

(Received May 10, 2016 Accepted July 20, 2016)

Keywords: Al-Mg-Si alloy, recrystallization, precipitation, grain growth, pinning force

\section{1. 緒言}

近年, 車体軽量化の観点から, 自動車用構造部材へのアル ミニウム合金の適用が増加している。自動車用板材において は，その成形性と強度の両立が重要である。 $\mathrm{Al}-\mathrm{Mg}-\mathrm{Si}$ 系合 金は，成形性が良好な焼なまし状態でプレス成形を行い，そ の後の塗装焼付け時に形成される $\mathrm{Mg}-\mathrm{Si}$ 相の $\beta^{\prime \prime}$ で，さらなる 高強度化が可能な合金であり，アルミニウム合金の中では自 動車用板材に適した合金であると言える ${ }^{1)}$ 。しかし，その強
度はいまだ $340 \mathrm{MPa}$ 級や $440 \mathrm{MPa}$ 級の鋼板 ${ }^{2)}$ に比べて劣るた め, 塗装焼付けによる高強度化を利用しつつ, プレス成形性 を損なわない強度-延性バランスのよい $\mathrm{Al}-\mathrm{Mg}-\mathrm{Si}$ 系合金を 開発できれば, さらなる需要拡大につながると考えられる。

一般に材料の強化手法は, 固溶強化, 析出強化および結晶 粒微細化強化などが挙げられる。析出強化の場合, 熱的に安 定な析出物を利用すると, 結晶粒微細化強化による高強度化 との複合的な高強度化が期待される。析出強化型アルミニウ ム合金の代表例としては7000系アルミニウム合金として知

*北海道大学 大学院工学研究院 材料科学部門（ Engineering, Faculty of Engineering, Hokkaido University (Kita 13, Nishi 8, Kita-ku, Sapporo-shi, Hokkaido 060-8628)

E-mail: ikeda.ken-ichi@eng.hokudai.ac.jp

**九州大学 大学院総合理工学府 物質理工学専攻大学院生（春日市）〔現在：JFEスチール株式会社〕 Graduate Student, Department of Molecular and Material Sciences, Interdisciplinary Graduate School of Engineering Sciences, Kyushu University (Kasuga-shi, Fukuoka)〔Present: JFE Steel Corporation ]

***九州大学 大学院総合理工学府 物質理工学専攻大学院生（春日市）〔現在：株式会社神戸製鋼所〕 Graduate Student, Department of Molecular and Material Sciences, Interdisciplinary Graduate School of Engineering Sciences, Kyushu University (Kasuga-shi, Fukuoka)〔Present: Kobe Steel, Ltd. ]

****九州大学 大学院総合理工学研究院 融合創造理工学部門（春日市） Department of Engineering Sciences for Electronics and Materials, Faculty of Engineering Sciences, Kyushu University (Kasuga-shi, Fukuoka)

*****九州大学 大学院工学研究院 材料工学部門 (福岡市) Department of Materials Science and Engineering, Faculty of Engineering, Kyushu University (Fukuoka-shi, Fukuoka) 
られる $\mathrm{Al}-\mathrm{Zn}-\mathrm{Mg}$ 系合金が挙げられるが，延性にそしく上記 のようなプレス成形には適さない。そこで， $\mathrm{Al}-\mathrm{Mg}-\mathrm{Si}$ 系合 金の組成を基本としたうえで，熱的に安定な析出物を析出さ せる元素を考慮した材料設計が必要である。本研究では，以 下に示す理由からアルミニウムとの金属間化合物を形成す るスカンジウム $(\mathrm{Sc})$ とジルコニウム $(\mathrm{Zr})$ を選択した。ア ルミニウムへ $\mathrm{Sc}$ と Z $\mathrm{r}$ を複合添加した合金は，優れた力学特 性を示すことから注目されて研究がなされてきた。 $500^{\circ} \mathrm{C}$ と $600^{\circ} \mathrm{C}$ に打ける $\mathrm{Al}-\mathrm{Sc}-\mathrm{Zr}$ 三元系状態図によると，母相に加え て $\mathrm{Al}_{3} \mathrm{Sc}$ と $\mathrm{Al}_{3} \mathrm{Zr}$ が共存する領域が広範囲に存在することな どが報告されている ${ }^{3)}$ 。この時, $\mathrm{Al}_{3} \mathrm{Sc}$ と $\mathrm{Al}_{3} \mathrm{Zr}_{\text {は }} \mathrm{Al}_{3}(\mathrm{Sc}, \mathrm{Zr})$ という複合相を形成する ${ }^{3)}$ 。特に $\mathrm{Al}_{3}(\mathrm{Sc}, \mathrm{Zr})$ は, $\mathrm{Al}_{3} \mathrm{Sc}$ より もエネルギー的，熱的㧍よび電子構造が安定であり，高温で も粗大化の速度が遅く，非常に安定な相であることが知られ ている ${ }^{4)}$ 。 $\mathrm{Al}-\mathrm{Sc}-\mathrm{Zr}$ 合金中の $\mathrm{Al}_{3}(\mathrm{Sc}, \mathrm{Zr})$ の析出形態は球状 であり, 中心部は Sc濃度が高く, 外周部は Zr 濃度が高いコ アシェル構造を形成する ${ }^{5)}$ 。これはアルミニウム中の $\mathrm{Sc}$ の拡 散速度が Zrに比べて極めて速く，その拡散速度の差により $\mathrm{Al}_{3} \mathrm{Sc}$ の析出の後に $\mathrm{Al}_{3} \mathrm{Zr}$ が被覆するように析出することに よることが報告されている。また，Al-Sc合金の研究におい て、Scを含んだアルミニウム過飽和固溶体は熱的に不安定 なため，その分解速度が著しく速いことが示されている ${ }^{4)} 。$ したがって， $\mathrm{Al}_{3} \mathrm{Sc}$ は母相内に短時間で均一に析出するため, $\mathrm{Al}_{3}(\mathrm{Sc}, \mathrm{Zr})$ も均一に析出することが考えられる。 $\mathrm{Al}_{3}(\mathrm{Sc}, \mathrm{Zr})$ の結晶構造は $\mathrm{L}_{2}$ 構造を有して扔り，母相のアルミニウムと の格子ミスフィットが約 $+1.3 \%$ と小さく，界面エネルギーが 低いので整合に析出する。そのうえ，凝固中に晶出した場合 は有効な再結晶粒の核生成サイトとしても働くと考えられ る。

このように, $\mathrm{Al}_{3}(\mathrm{Sc}, \mathrm{Zr})$ は「母相内に均一に析出する」, 「母相との整合性が高い」,「熱的安定性が高い」という3つ の特長を有していることから，析出強化と結晶粒微細化強化 に上る強度向上が期待される。結晶粒微細化強化は他の強化 法に比べて延性の低下が少ないため, 複合添加による延性を 維持したままの高強度化が可能であると考えられる。

これまで, Al-Sc-Zr系三元合金に扔いては過飽和固溶体

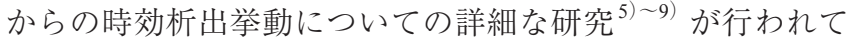
いる。その結果, $\mathrm{Al}_{3}(\mathrm{Sc}, \mathrm{Zr})$ は優れた特性を示す反面, 熱 的安定性が高いゆえに過飽和固溶体への分解に高温長時間を 有することが明らかとなっている。例えば, 岩村らの検討 ${ }^{5)}$ では $\mathrm{Al}_{3}(\mathrm{Sc}, \mathrm{Zr})$ の分解のために $650^{\circ} \mathrm{C}$ で $200 \mathrm{~h}$ という高温長 時間の溶体化処理を行っているが，このような熱処理は実用 上非現実的である。実用材料への展開を考えるうえでは，上 記の上うな高温かつ長時間の溶体化処理と析出処理を考元る のではなく，凝固組織中に第二相粒子（晶出物や析出物）が 存在する状態での最適な加工熱処理を検討することが現実的 である。本研究では上記の理由でこれまでほとんど研究がな されていなかった $\mathrm{Sc}, \mathrm{Zr}$ 複合添加 $\mathrm{Al}-\mathrm{Mg}-\mathrm{Si}$ 系合金を作製し 粒子の存在状態と加工熱処理に伴う再結晶粒成長挙動を詳細 に調査することで, $\mathrm{Sc}, \mathrm{Zr}$ 複合添加 $\mathrm{Al}-\mathrm{Mg}-\mathrm{Si}$ 系合金の実用材 料としての可能性について検討した。

\section{2. 実 験方 法}

本研究では，Al-Mg-Si 合金に $\mathrm{Sc}$ と Zrを複合添加した

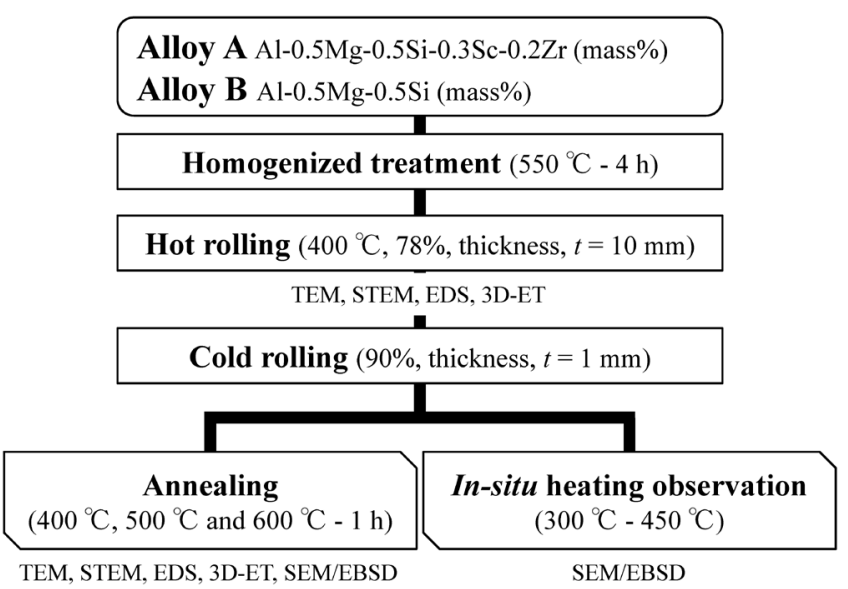

Fig. 1 Production and experimental process of samples.

$\mathrm{Al}-0.5 \mathrm{Mg}-0.5 \mathrm{Si}-0.3 \mathrm{Sc}-0.2 \mathrm{Zr}$ （数字は mass\%）合金（以下 $\mathrm{A}$ 合金）と $\mathrm{Al}-0.5 \mathrm{Mg}-0.5 \mathrm{Si}$ 合金（以下 $\mathrm{B}$ 合金）を用いた。両 合金を，均質化処理 $\left(550^{\circ} \mathrm{C}-4 \mathrm{~h}\right)$ および熱間圧延（圧延開 始温度 $400^{\circ} \mathrm{C}$, 圧下率 $78 \%$, 厚さ $10 \mathrm{~mm}$ ) を施した。両合 金の熱間圧延試料については, 内部に存在する第二相粒子 の分布状態や組成を明らかにするために, 透過電子顕微鏡 法（Transmission Electron Microscopy: TEM）抢よび走査透

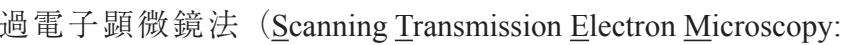
STEM）による観察ならびにエネルギー分散X線分光法に よる組成分析 (STEM-Energy Dispersive X-ray Spectroscopy: EDS）を行った。また，第二相粒子の形態を明らかにする ために三次元電子線卜モグラフィ（르 Dimensional Electron Tomography: 3D-ET）法を用いたSTEM観察も実施した。 3D-ET 観察には Mel-Build社製HATA-8075を試料ホルダとし て用い，傾斜角度範囲 $\pm 75^{\circ}$, STEM像取得角度 $1 \sim 2^{\circ}$ で連続 傾斜像を取得 $L$, 逐次反復再構成法 ( Reconstruction Technique: SIRT) により三次元再構築を行っ た。

熱間圧延試料に，圧下率 $90 \%$ の冷間圧延を施した冷間圧 延試料を対象として, 再結晶挙動の評価を目的として加工 熱処理に伴う組織変化の観察を行った。冷間圧延試料に加 えて, 冷間圧延後に $400^{\circ} \mathrm{C}, 500^{\circ} \mathrm{C}$ および $600^{\circ} \mathrm{C} て ゙ 1 \mathrm{~h}$ の熱処 理を施した冷間圧延一焼なまし試料について, 圧延方向断 面 (RD面) の電子線後方散乱回折（SEM/EBSD: Electron Back Scatter Diffraction）法による結晶方位解析を行った。一 部の試料については，粒子の分布状態等を明らかにするた めに, TEM/STEM観察と3D-ET法による組織評価を行った。 また，同一視野の熱処理による組織変化を明らかにするため に, SEM 用加熱ステージを用いたその場加熱 SEM/EBSD解 析を $300^{\circ} \mathrm{C}$ から $450^{\circ} \mathrm{C}$ まで $50^{\circ} \mathrm{C}$ 間隔で行った。各温度での保 持時間は $1.5 \mathrm{~h}$ とし, 解析面は圧延面 (ND面) とした。 $\mathrm{SEM} /$ EBSD法による観察試料の作製手法は $\mathrm{Al}-\mathrm{Mg}-\mathrm{Si}$ 系合金の結 晶方位解析を行った著者らの研究グループの手法 ${ }^{10)}$ と同様 の手法を用いた。以上で得られた， $\mathrm{A}$ 合金の組織情報すなわ ち, 冷間圧延試料の組織, 第二相粒子の存在状態掞よび冷間 圧延一焼なまし試料の組織から再結晶挙動に及ほす $\mathrm{Sc}$ と $\mathrm{Zr}$ 添加の影響について検討した。Fig. 1 に試料の製造工程と実 験の流れを示す。 

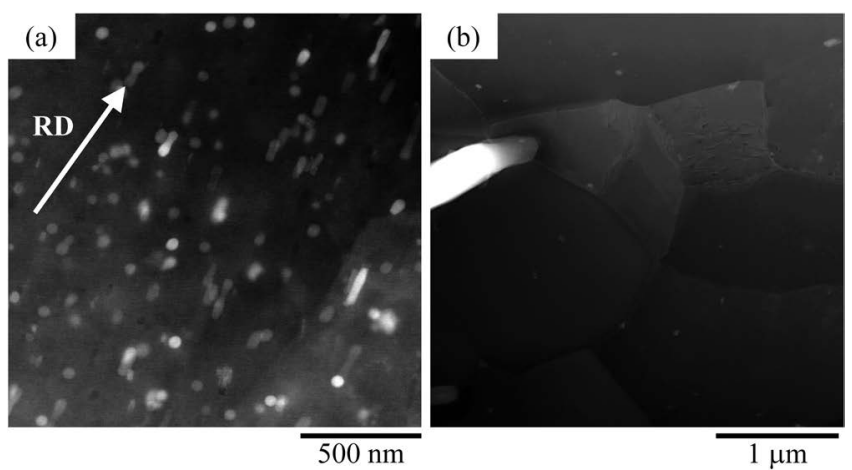

Fig. 2 HAADF-STEM images of hot-rolled sheets: (a) Al$\mathrm{Mg}-\mathrm{Si}-\mathrm{Sc}-\mathrm{Zr}$ (Alloy A) and (b) Al-Mg-Si (Alloy B).
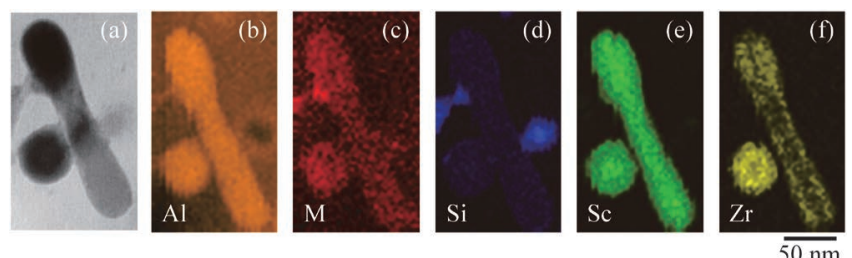

Fig. 3 (a) HAADF-STEM image and (b)-(f) STEM-EDS elemental maps of particles in hot-rolled sheet of Alloy A.
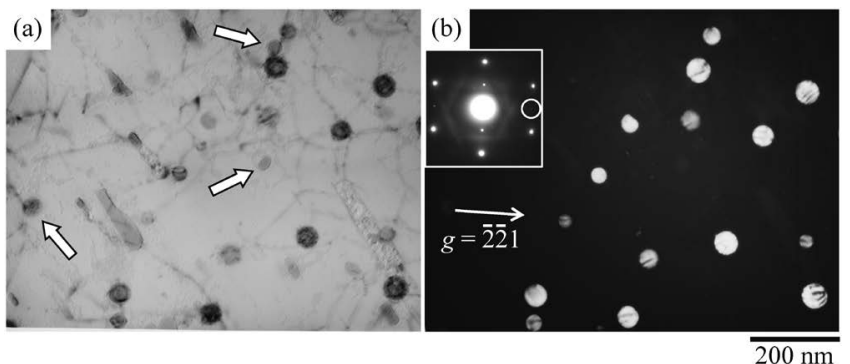

Fig. 4 (a) BF-TEM image and (b) DF-TEM of particles in hot-rolled sheets of Alloy A.

\section{3. 実験結果および考察}

\section{1 熱間圧延試料の微視組織解析}

$\mathrm{A}$ 合金と B 合金の熱間圧延試料の圧延方向平行横断面（TD 面）からの観察の結果，A合金のND方向の結晶粒幅は6〜 $18 \mu \mathrm{m}$ ，B合金の結晶粒幅は 65〜 300 $\mu \mathrm{m}$ であり，Sc と Zr を複 合添加することによって，熱間圧延の段階で結晶粒が微細 化することが明らかになった。その理由としては，鋳造段 階において $\mathrm{A}$ 合金では $\mathrm{Al}_{3}(\mathrm{Sc}, \mathrm{Zr})$ が凝固中に晶出し，結晶 粒が微細化したと考えられる。Fig. 2 は，両合金の熱間圧延 試料の結晶粒内部組織の HAADF（High-Angle Annular DarkField)-STEM像である。図中で明るいコントラストで示され る領域は，原子番号の大きな元素が存在することを示してお り，A合金中には，球状や棒状などの様々な形態の第二相粒 子が存在することが明らかになった。Fig. 2(a) のHAADFSTEM像から第二相粒子のアスペクト比を求めた結果, 1.5 以下の球状粒子と 1.5 以上の棒状粒子が混在しており, 棒状 粒子の長軸が圧延方向に配向していることがわかった。各粒 子のEDS 点分析の結果, 球状粒子の主要成分は $\mathrm{Al}, \mathrm{Sc}$ おび $\mathrm{Zr}$ であり，棒状粒子は $\mathrm{Al}$ と $\mathrm{Si}$ もしくは， $\mathrm{Al}, \mathrm{Sc}$ および $\mathrm{Zr}$ で

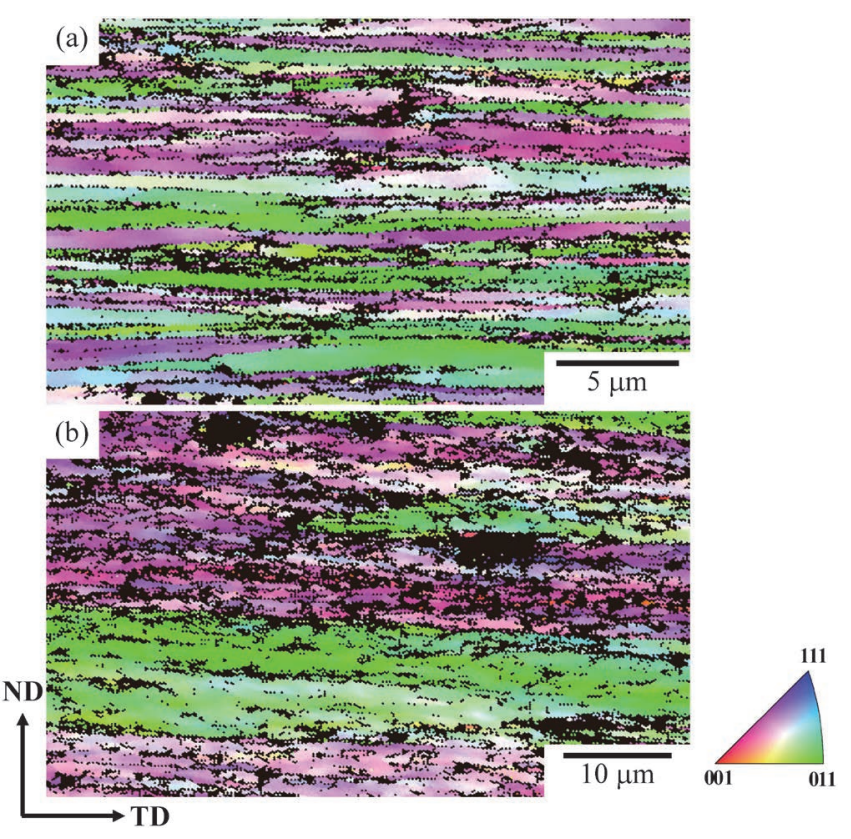

Fig. 5 ND plane crystal orientation distribution maps of cold rolled sheets: (a) Alloy A and (b) Alloy B. (a) $\mathrm{A}-400$

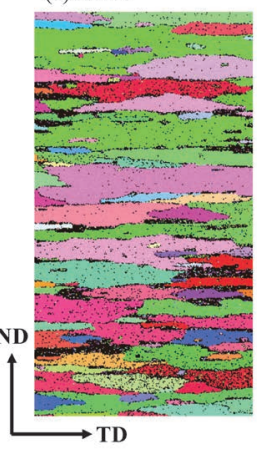

(b) A-500

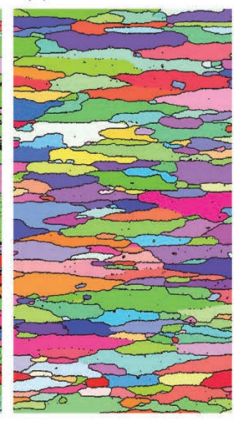

(c) A-600

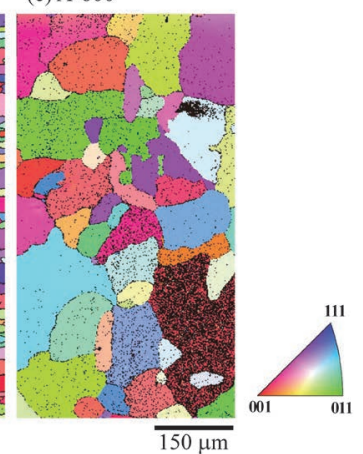

Fig. 6 ND plane crystal orientation distribution maps of cold rolled and annealed sheets of Alloy A: (a) A-400, (b) A-500 and (c) A-600.
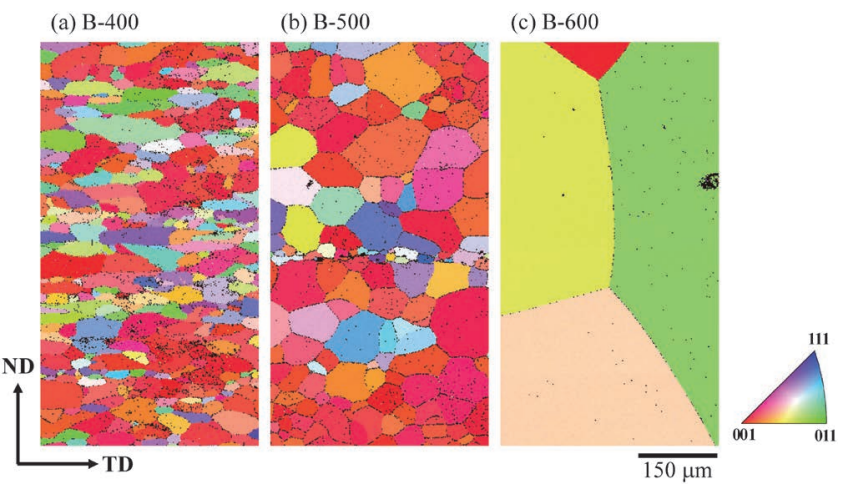

Fig. 7 ND plane crystal orientation distribution maps of cold rolled and annealed sheets of Alloy B: (a) B-400, (b) B-500 and (c) B-600.

あった。本研究で用いた合金は $\mathrm{Mg}_{2} \mathrm{Si}$ 安定相が存在すること を考えると過剩 $\mathrm{Si}$ 合金に分類される合金組成であるため, $\mathrm{Si}$ 単体で晶出もしくは析出することも予想される。したがっ て，棒状粒子に上記の 2 種類の組成が存在したことが考え 
られる。Fig. 3 にA合金の熱間圧延試料に存在するとともに $\mathrm{Al}, \mathrm{Sc}$ およびZr 組成を有する球状粒子と棒状粒子の STEMEDS 元素マッピングを示す。 Sc と Z r のマッピング像におい て, $\mathrm{Al}-\mathrm{Sc}-\mathrm{Zr}$ 三元系合金で報告された $\mathrm{Al}_{3}(\mathrm{Sc}, \mathrm{Zr})$ 析出物 ${ }^{5)}$ と同様のコアシェル構造が観察された。Fig. $4(\mathrm{a})$ に球状粒 子と棒状粒子が同一結晶粒内に存在する領域において観察し たTEM明視野像を示す。また, Fig. 4(b) の内挿図にはこの 領域の電子線入射方向〈114〉の電子回折図形を示している が， $\mathrm{L}_{2}$ 構造に起因する規則格子反射が確認できる。内挿図 中の白丸で示した規則格子反射の回折波で結像したTEM暗 視野像を Fig. 4(b) に示す。明視野像中に存在する球状粒子 の多くはこの回折波により励起されていることから, 母相と 特定の方位関係を持って析出した $\mathrm{Al}_{3}(\mathrm{Sc}, \mathrm{Zr})$ と考えられる。 これらの球状粒子について母相の $2 \overline{2} 0$ 回折波を用いた二波励 起条件での明視野観察を行った結果，波状のモアレを確認 することができた。整合粒子の場合，粒子の位置にAshbyBrownコントラストと呼ばれるコーヒー豆状のひずみコント ラストが観察されるが，非整合化が進むにつれて，波状のコ ントラストに変化することが報告されている ${ }^{11)}$ 。したがっ て, Fig. 4(b) で励起された球状粒子は非整合粒子であるこ とが明らかになった。一方，明視野像中の白矢印で示した球 状粒子や棒状粒子は，暗視野像には励起されなかった。棒状 粒子が $\mathrm{L}_{2}$ 構造を有する $\mathrm{Al}_{3}(\mathrm{Sc}, \mathrm{Zr})$ であるかどうかを判別 するために抽出レプリカ法により TEM試料作製を行い，析 出物のみの電子回折図形を解析した。その結果, $\mathrm{L}_{2}$ 構造 を有する $\mathrm{Al}_{3}(\mathrm{Sc}, \mathrm{Zr})$ であることが確認できた。球状粒子と 異なるのは母相との方位関係を有していない点のみである。 Norman らが報告した Al-Sc-Zr 三元合金鋳造材やFullerらが 報告した Sc, Zr 複合添加5754アルミニウム合金熱間圧延材の 研究結果 ${ }^{12}$,13) をふまえると，棒状粒子は鋳造後の凝固の際 に共晶反応により生成したと考えられる。また，励起されな かった球状粒子（白矢印）においては，STEM-EDSの結果, Sc 濃化領域が球状粒子内に存在することがわかった。さら に, STEM-EDS と 3D-ETを組み合わせて元素分析を行ったと ころ, Sc 濃化領域は円筒状に存在することが確認された ${ }^{14)}$ 。 これは棒状粒子が熱間圧延中に分断され，球状化したことが 予想される。

以上の結果より， $\mathrm{Al}-\mathrm{Mg}-\mathrm{Si}$ 合金に $\mathrm{Sc}$ と Zrを微量添加する と, $\mathrm{Ll}_{2}$ 構造を有する $\mathrm{Al}_{3}(\mathrm{Sc}, \mathrm{Zr})$ が存在することが明らかに なった。加工熱処理工程において，その存在形態が異なり, 熱間圧延試料中に存在するのは，2種類の球状粒子および棒 状粒子であった。棒状粒子と母相との方位関係を有しない球 状粒子は凝固時に形成され，母相との方位関係を有する球状 粒子は，均質化処理中に生じたことが示唆された。

\section{2 冷間圧延試料と焼なまし試料の微視組織解析}

Fig. 5 は各合金の冷間圧延後のRD面の結晶方位分布図で ある。各結晶のND面の方位で色づけを行っている（以下， 同様の方法で結晶方位分布を示す)。A合金の方が，結晶粒 幅が小さいことがわかる。3.1節で述べたように，熱間圧延 後に $\mathrm{A}$ 合金には $\mathrm{Al}_{3}(\mathrm{Sc}, \mathrm{Zr})$ が存在していることで結晶粒幅 が微細化しており，冷間圧延後にもその影響が残っているこ とになる。両合金ともにアルミニウム合金の典型的な強圧延 集合組織である Brass方位, Copper方位およびS方位で占め られており，冷間圧延後の集合組織に大きな違いは見られな
かった。

Fig. 6 は, A 合金の冷間圧延試料に $400^{\circ} \mathrm{C}(\mathrm{A}-400)$, $500^{\circ} \mathrm{C}$ (A-500) および $600^{\circ} \mathrm{C}(\mathrm{A}-600)$ で $1 \mathrm{~h}$ の焼なましを施 した後のRD面での結晶方位分布図である。A-400 と A-500 は伸長した結晶粒が確認され，冷間圧延の影響が残存してい ることが考えられるが，A-600では，ND方向への粒成長が 生じていることがわかった。一方，Fig.7には，B合金の各 熱処理後（B-400, B-500 およびB-600）のRD面の結晶方位分 布図を示している。B-400には冷間圧延の影響が残り伸長し た結晶粒が見受けられるが，B-500では等軸粒に成長してい た。また，B-600の観察視野には，4個の結晶粒しか確認で きなかったことから, $1 \mathrm{~mm}$ の板厚方向には2〜3個の結晶粒 のみ存在していると考えられる。

Fig. 6 と Fig. 7 で示した結晶方位情報より, 集合組織成分の 分布状態を確認したところ, B 合金の焼なまし試料ではCube 方位粒の占有率が高い再結晶集合組織を形成していたが，A 合金ではランダムな結晶方位分布となっていた。以上の結 果より, $\mathrm{Al}_{3}(\mathrm{Sc}, \mathrm{Zr})$ は冷間圧延後の焼なまし過程において, 無添加の $\mathrm{Al}-\mathrm{Mg}-\mathrm{Si}$ 合金とは異なる再結晶粒成長挙動を示す ことが明らかになった。また，集合組織のランダム化が起き ていることから, 成形性の向上に寄与する組織制御の可能性 を有することが示唆された。

\section{3 再結晶粒成長に及ぼす $\mathrm{Al}_{3}(\mathrm{Sc}, \mathrm{Zr})$ 粒子の影響}

3.2 節で示したように, $\mathrm{Al}_{3}(\mathrm{Sc}, \mathrm{Zr})$ 粒子によって $\mathrm{Al}-\mathrm{Mg}-$ $\mathrm{Si}$ 合金は加工熱処理に伴う組織形成過程が変化することが明 らかになった。そこで, $\mathrm{Al}_{3}(\mathrm{Sc}, \mathrm{Zr})$ 粒子が組織形成にどの ように影響を及ぼすのかについて組織観察結果をもとに定量 的に評価を行う。冷間圧延後の焼なましによって, 加工組織 は回復過程を経て, 一次再結晶, 正常粒成長もしくは二次再 結晶へと組織形成が進行する。この過程において，再結晶の 駆動力と粒子によるZener force（粒界ピニング力）の大小関 係によって再結晶の進行もしくは遅延が決定する。すなわ ち, 『再結晶の駆動力 $>$ Zener force』となれば, 再結晶は進行 し, 『再結晶の駆動力 $<$ Zener force』となれば再結晶は遅延す る。本研究では, 再結晶の駆動力を SEM/EBSD法によって 得られた結晶方位情報から, $\mathrm{Al}_{3}(\mathrm{Sc}, \mathrm{Zr})$ 粒子の Zener force を TEM/STEM観察と 3D-ET 法によって得られた粒子の空間 分布情報から求め, 両者の比較を行った。

\subsection{1 冷間圧延試料の一次再結晶の駆動力}

冷間加工が施された金属材料の焼なまし（熱処理）に伴う 再結晶は一次再結晶と呼ばれており, 加工により導入された 蓄積ひずみエネルギーが一次再結晶の駆動力となる。冷間圧 延により導入される転位下部組織は焼なまし初期において回 復が起こるため, 結晶粒内は亜結晶粒が多く存在すると考え られる。本研究では，SEM/EBSD法で得られた冷間圧延試 料の亜結晶粒界エネルギーを蓄積ひずみエネルギーとみなし て駆動力を評価した ${ }^{15)}$ 。Fig. 5 で示した A 合金の冷間圧延試 料の方位情報より, 測定点間の方位差が $15^{\circ}$ 以下となる境界 を観察面に対して垂直な亜結晶粒界とみなし, 式(1) に示す Read-Shockleyの式 ${ }^{16), 17)}$ を用いて方位差， $\theta_{i}$ における粒界工 ネルギー， $\gamma_{i}$ を算出した。

$$
\gamma_{i}=\gamma_{\mathrm{m}} \frac{\theta_{i}}{\theta_{\mathrm{m}}}\left(1-\ln \frac{\theta_{i}}{\theta_{\mathrm{m}}}\right)
$$


ここで， $\gamma_{\mathrm{m}}$ と $\theta_{\mathrm{m}}$ は大角粒界のエネルギーと方位差であり, 本研究ではそれぞれ $0.32 \mathrm{~J} / \mathrm{m}^{2}$ と $15^{\circ}$ とした ${ }^{18)}$ 。SEM/EBSD法 では，正六角形ピクセルを用いた結晶方位分布図を作成して おり, 測定点間距離, $x$ を用いると, 測定点間の境界長さは $x / \sqrt{3}$ となる。この長さを単位長さとして, 観察視野内の方 位差 $\theta_{i}$ を有する亜結晶粒界の個数, $n_{i}$ を用いて, 単位長さあ たりの亜結晶粒界エネルギーは $n_{i} \cdot \gamma_{i} \cdot x / \sqrt{3}$ で求めることがで きる。観察視野内の $15^{\circ}$ 以下の亚結晶粒界エネルギーの総和, $\gamma_{\mathrm{t}}$ は, $\gamma_{\mathrm{t}}=\sum \gamma_{i}$ となる。 $\gamma_{\mathrm{t}}$ を観察面積で除することで, 一次再 結晶の駆動力を求める。Fig. 5 中の黑の測定点は, 方位解析 の信頼性が悪い点であることから, 解析対象の面積から除外 したうえで求めた観察視野面積, $S$ を用いると, 次式により 一次再結晶の駆動力, $P_{\mathrm{I}}\left[\mathrm{J} / \mathrm{m}^{3}=\mathrm{Pa}\right]$ を求めることができる。

$$
P_{\mathrm{I}}=\frac{\gamma_{\mathrm{t}}}{S}
$$

Fig. 5 (a) に示すA合金冷間圧延試料の方位差 $15^{\circ}$ 以下の亜 結晶粒界長さより， $\gamma_{\mathrm{t}}$ と $S$ を求めたところ，それぞれ $7.69 \times$ $10^{-4} \mathrm{~J} / \mathrm{m}$ と $6.49 \times 10^{-10} \mathrm{~m}^{2}$ となり, 式(2) から $P_{\mathrm{I}}$ を求めたところ, $1.18 \mathrm{MPa}$ となった。この值と次項で示す粒子によるZener force および正常粒成長の駆動力との比較を行う。

\section{3. $3.2 \mathrm{Al}_{3}(\mathrm{Sc}, \mathrm{Zr})$ 粒子によるZener force}

結晶粒内に存在する析出物などの分散粒子は，転位の移動 を阻害することで粒子分散強化による強度増加に寄与する が, 結晶粒径と集合組織制御の観点からも重要な組織因子で もある。再結晶の素過程は粒界移動であるため, 結晶粒内の 分散粒子が粒界移動を阻害することで, 結晶粒微細化など の諸現象に繋がることになる。本研究で用いた $\mathrm{Al}-\mathrm{Mg}-\mathrm{Si}$ 合 金に Sc と Zr を微量添加すると, 晶出物や析出物などの多く の $\mathrm{Al}_{3}(\mathrm{Sc}, \mathrm{Zr})$ 粒子が存在する。本項では, $500^{\circ} \mathrm{C}$ と $600^{\circ} \mathrm{C} て ゙$ 焼なましを施した試料について, 試料内に存在する粒子の Zener force ${ }^{18), 19)}$ について検討する。粒子と粒界の相互作用は 両者が形成する界面の整合性によって大きく変化する。Fig. 8 (a) は母相と非整合な方位関係となる粒子が粒界移動に及 ぼす影響を示した模式図である。粒界移動の方向は図中のY 方向であり, 移動方向と逆向きに働く力が粒子によるZener forceである。Fig. 8(a) より粒界エネルギー, $\gamma_{\mathrm{gb}}$ と析出粒子 径， $d$ を用いてZ Zener forceを表すことができ，非整合粒子 1 個あたりのZener force, $F_{i}$ は，

$$
F_{i}=\pi d \cos \alpha \cdot \gamma_{\mathrm{gb}} \sin \alpha
$$

となる。ここで $\alpha$ は粒界と粒子のなす角度である。 $\alpha=45^{\circ}$ の とき, 最大值 $F_{i s}$ をり，その值は，
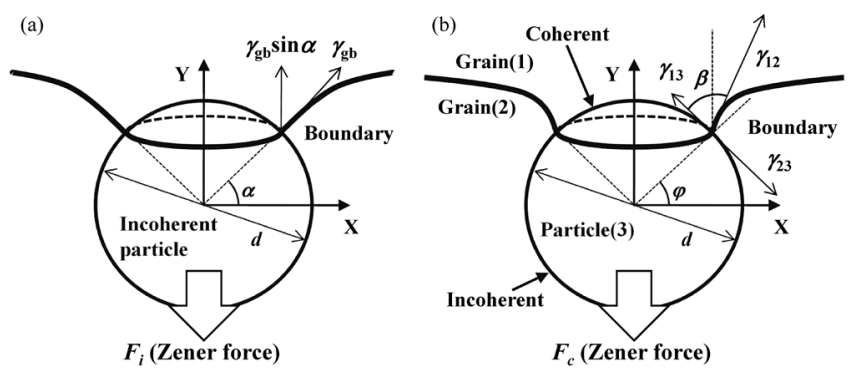

Fig. 8 The interaction between a grain boundary and a spherical particle: (a) an incoherent particle and (b) a coherent particle.

$$
F_{i s}=\frac{\pi d \gamma_{\mathrm{gb}}}{2}
$$

となる。これをもとに単位体積あたりの非整合粒子の Zener force, $P_{i}$ を求める。単位体積あたりの非整合粒子の数を $N_{v}$ と すると, 粒界が単位面積あたりに接触する粒子の数, $N_{s}$ は, $N_{s}=d \cdot N_{v}$ となる。これより, 存在する粒子に明瞭な大きさ分 布がない場合, 粒界の単位面積あたりに対して非整合粒子が 有するZ Zener force, $P_{i}$ は式(5) で示される。

$$
P_{i}=N_{s} \cdot F_{i s}=\frac{N_{v} \pi d^{2} \gamma_{\mathrm{gb}}}{2}
$$

Fig. 8（b）は，母相と整合な方位関係を有する粒子と粒界 移動の関係を示した模式図である。粒界移動の方向は非整合 粒子の場合と同様であり, この粒子は Grain（1）に対して整 合関係，Grain（2）に対して非整合関係になる。粒子表面と 粒界の接点において，界面エネルギーの釣り合いを考える と,

$$
\gamma_{23}=\gamma_{13}+\gamma_{12} \cos \beta
$$

となる。ここで， $\gamma_{12}$ は粒界エネルギー， $\gamma_{13}$ はGrain（1）と 粒子の整合界面エネルギーおよび $\gamma_{23}$ は Grain（2）と粒子の 非整合界面エネルギーであり， $\beta$ は Fig. 8(b) に示す角度とな る。これより, 整合粒子 1 個あたりのZ Zener force, $F_{c}$ は粒界と 整合粒子のなす角度， $\varphi$ を用いると

$$
F_{c}=\pi d \cos \varphi \cdot \gamma_{12} \cos (\beta-\varphi)
$$

で表される。 $\varphi=\beta / 2$ および $\beta=0$ のとき, 最大值 $F_{c s}$ をとり，そ の值は

$$
F_{c s}=\pi d \gamma_{12}
$$

となる。非整合粒子の場合と同様に, 粒界の単位面積あたり に対して整合粒子が有するZ Zener force, $P_{c}$ は式(9) で示され る。

$$
P_{c}=N_{s} \cdot F_{c s}=N_{v} \pi d^{2} \gamma_{12}
$$

式(5)と式（9）を比較すると, 粒界と粒子のなす角度が $90^{\circ}$ 以下となる場合, 整合粒子のZener forceが大きくなる。

本研究では, $\mathrm{A}$ 合金の $500^{\circ} \mathrm{C}$ おび $600^{\circ} \mathrm{C}$ 焼なまし試料 中 (A-500, A-600) の粒子の TEM/STEM観察および3D-ET 法による解析から, 粒子の整合性および平均粒子径, $d$ と数 密度, $N_{v}$ を求めた。Fig. 9 (a) と（c）は, それぞれA-500 と A-600の HAADF-STEM 像である。また, Fig. 9(b) と（d) は, 3D-ET法を用いて取得したA-500 とA-600 中に存在す る粒子の三次元再構築像であり, 同一領域を $45^{\circ}$ 回転させ た像を並列させて示している。これらの視野を含め, 複数 視野の空間分布情報をもとに両者の $d$ と $N_{v}$ を求めたところ, A-500では $d=45.7 \mathrm{~nm}, N_{v}=1.15 \times 10^{20}$ 個 $/ \mathrm{m}^{3}$ となり, A-600では $d=89.9 \mathrm{~nm}, N_{v}=3.25 \times 10^{19}$ 個 $/ \mathrm{m}^{3}$ となった。また, 棒状粒子の存 在頻度は大きく減少していることが明らかになった。した がって, Zener forceの算出には棒状粒子は無視できると考え た。また，TEM観察により，球状粒子の整合性を評価した 結果，A-600 中の粒子はほぼすべてが非整合粒子となってお り, A-500では, 半整合粒子と非整合粒子が混在することが 

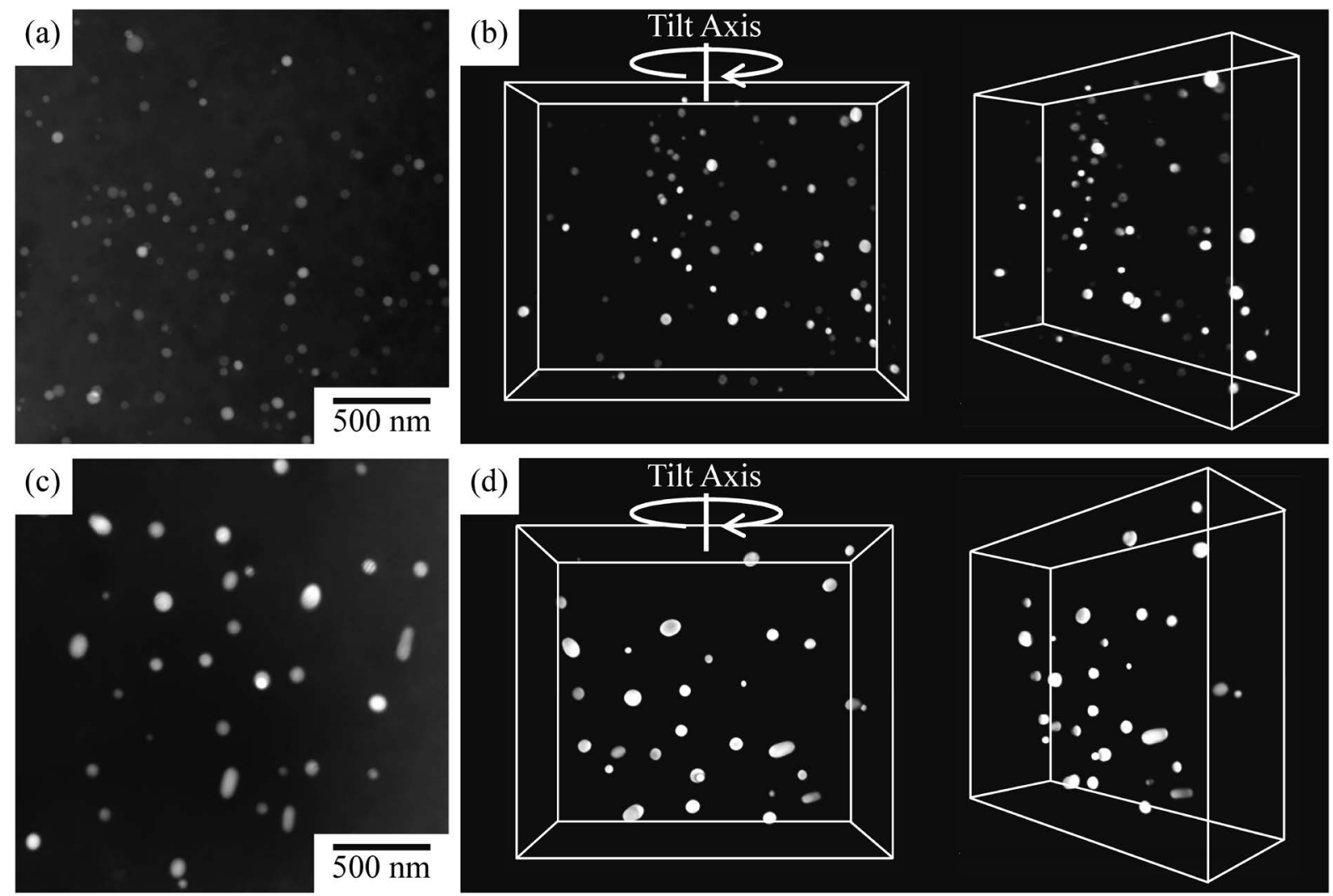

Fig. 9 HAADF-STEM images of cold-rolled and annealed sheets of Alloy A: (a) A-500 and (b) A-600.

わかった。解析の結果, A-500の半整合粒子は, $d=46.3 \mathrm{~nm}$, $N_{v}=3.10 \times 10^{19}$ 個 $/ \mathrm{m}^{3}$ ，非整合粒子は $d=45.1 \mathrm{~nm}, N_{v}=8.38 \times 10^{19}$ 個/ $\mathrm{m}^{3}$ であった。したがって，A-500のZener forceの評価には， 非整合粒子には式(5) を，半整合粒子には式(9) を用いて 算出した。また, 粒界エネルギー, $\gamma_{\mathrm{gb}}$ および $\gamma_{12}$ は大角粒界 の粒界エネルギーとみなし， $0.32 \mathrm{~J} / \mathrm{m}^{2}$ を用いた。その結果， A-500 試料の Zener force, $P_{z 500}\left(=P_{i}+P_{c}\right)$ は $0.16 \mathrm{MPa}, \mathrm{A}-600$ の Zener force, $P_{z 600}\left(=P_{i}\right)$ は $0.13 \mathrm{MPa}$ となった。

\subsection{3 焼なましに伴う粒成長の駆動力}

一次再結晶後には，焼なましに伴い結晶粒の成長が生じ る。粒成長過程では, その駆動力は湾曲した粒界が平面にな ろうとする力であり，粒界エネルギーに依存する。正常粒成 長および二次再結晶 (異常粒成長) の駆動力は式(10) で示 される ${ }^{18)}$ 。

$$
P_{\mathrm{II}}=\frac{A \gamma_{\mathrm{gb}}}{R}
$$

ここで，Rは粒界の曲率半径であり, 結晶粒径にも比例す ることが示されており，A は定数である。式(10)より，結 晶粒径が小さくなるほど，粒成長の駆動力は大きくなるこ とがわかる。そこで本研究では，A-500 とA-600の最小結 晶粒径より, 粒成長の最大駆動力を求めた。Fig. 6 の結晶方 位分布図より，A-500,A-600の最小結晶粒半径はそれぞれ $4.1 \mu \mathrm{m}$ と $7.9 \mu \mathrm{m}$ であった。 $A=1$ として, $\gamma_{\mathrm{gb}}=0.32 \mathrm{~J} / \mathrm{m}^{2}$ を用い ると, 両試料の駆動力は, A-500で $P_{\mathrm{II} 500}=0.078 \mathrm{MPa}, \mathrm{A}-600$ で $P_{\mathrm{II} 600}=0.041 \mathrm{MPa}$ となった。

以上の各項の検討により, 一次再結晶の駆動力 $P_{\mathrm{I}}(=1.18 \mathrm{MPa})$ は, Zener force よりも極めて大きいことがわ かる。すなわち, A 合金の $500^{\circ} \mathrm{C} と 600^{\circ} \mathrm{C}$ の焼なまし過程に
おいて $\mathrm{Al}_{3}(\mathrm{Sc}, \mathrm{Zr})$ 球状粒子は一次再結晶への強い障害には ならないことが予想される。一方, 一次再結晶後の粒成長の 駆動力と比較すると, Zener force は大きいため, $\mathrm{Al}_{3}(\mathrm{Sc}, \mathrm{Zr})$ 球状粒子は粒成長の障害になり得ることが示唆された。

\section{4 その場加熱 SEM/EBSD 解析による再結晶挙動の評価}

3.3 節で検討したように, $\mathrm{Al}_{3}(\mathrm{Sc}, \mathrm{Zr})$ 球状粒子は, 一次再 結晶よりもその後の粒成長挙動に影響を及ぼすことが示唆さ れた。そこで, 同一視野の加熱 SEM/EBSD解析による再結 晶挙動を明らかにすることで上記予測結果について検討す る。

Fig. 10は, A 合金の冷間圧延試料の解析結果である。図 中の黒で示されている領域は, 高ひずみ帯や粒界の存在な どの理由で解析信頼性が悪い領域である。熱処理前の試料

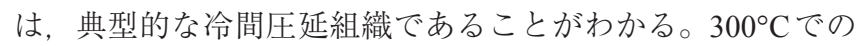
熱処理後は, 冷間圧延組織とほぼ同様の組織であり, 大きな 変化は見られなかったが, $350^{\circ} \mathrm{C}$ の熱処理で粒成長が開始し た。 $350^{\circ} \mathrm{C}$ の熱処理で視野中の冷間圧延組織はほぼ消滅した が， $450^{\circ} \mathrm{C}$ までの熱処理でその後の粒成長が生じていないこ とがわかる。また，再結晶粒界が湾曲している部分が多く, $\mathrm{Al}_{3}(\mathrm{Sc}, \mathrm{Zr})$ 粒子による粒界のピン止めが起きていることが 示唆された。

一方，Fig. 11 はB合金の冷間圧延試料の解析結果である。 熱処理前の試料は $\mathrm{A}$ 合金と同様に冷間圧延組織を有していた が, $300^{\circ} \mathrm{C}$ の熱処理で急激に粒成長しており, この段階でほ ぼ冷間圧延組織は蚕食されていた。また, その後の温度保持 過程, $350 \sim 450^{\circ} \mathrm{C} て ゙ の$ 熱処理においてその組織が大きく変 化する様子を捉えることができた。

アルミニウム合金の主な圧延集合組織と再結晶集合組織 

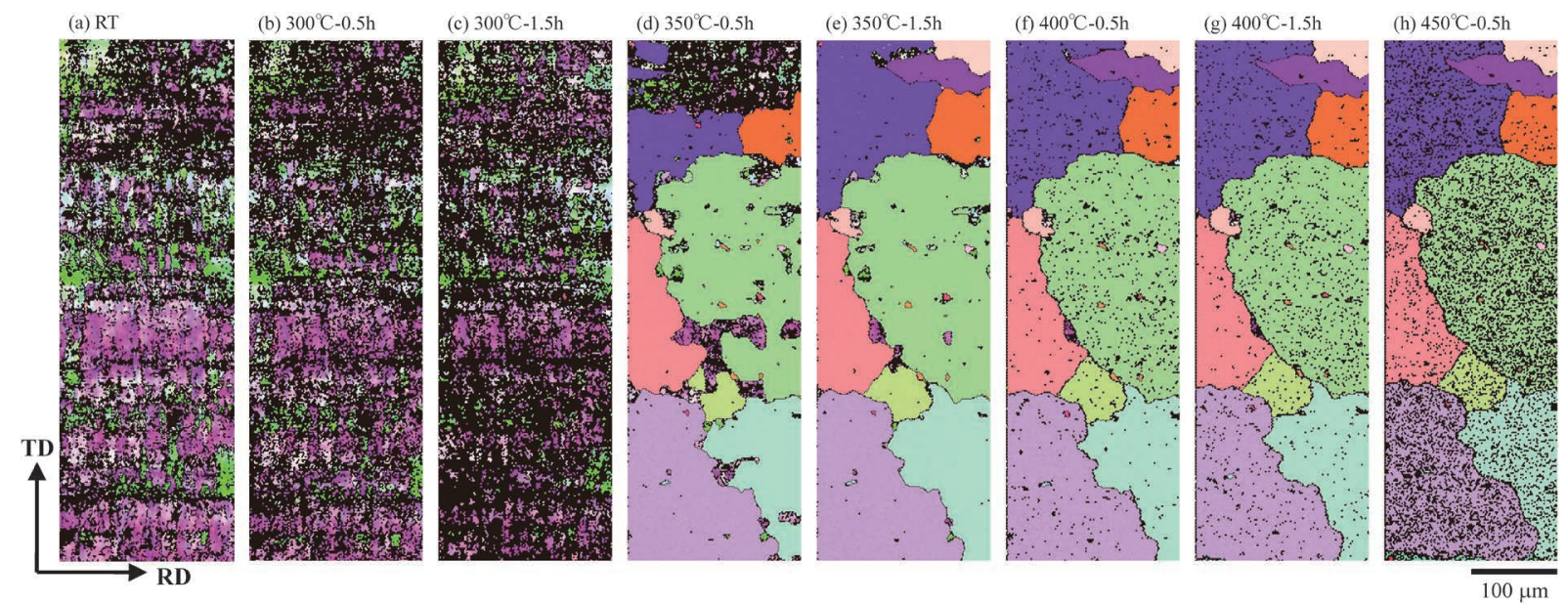

Fig. 10 ND plane crystal orientation distribution maps of cold rolled sheets of Alloy A by using in-situ heating EBSD analysis.
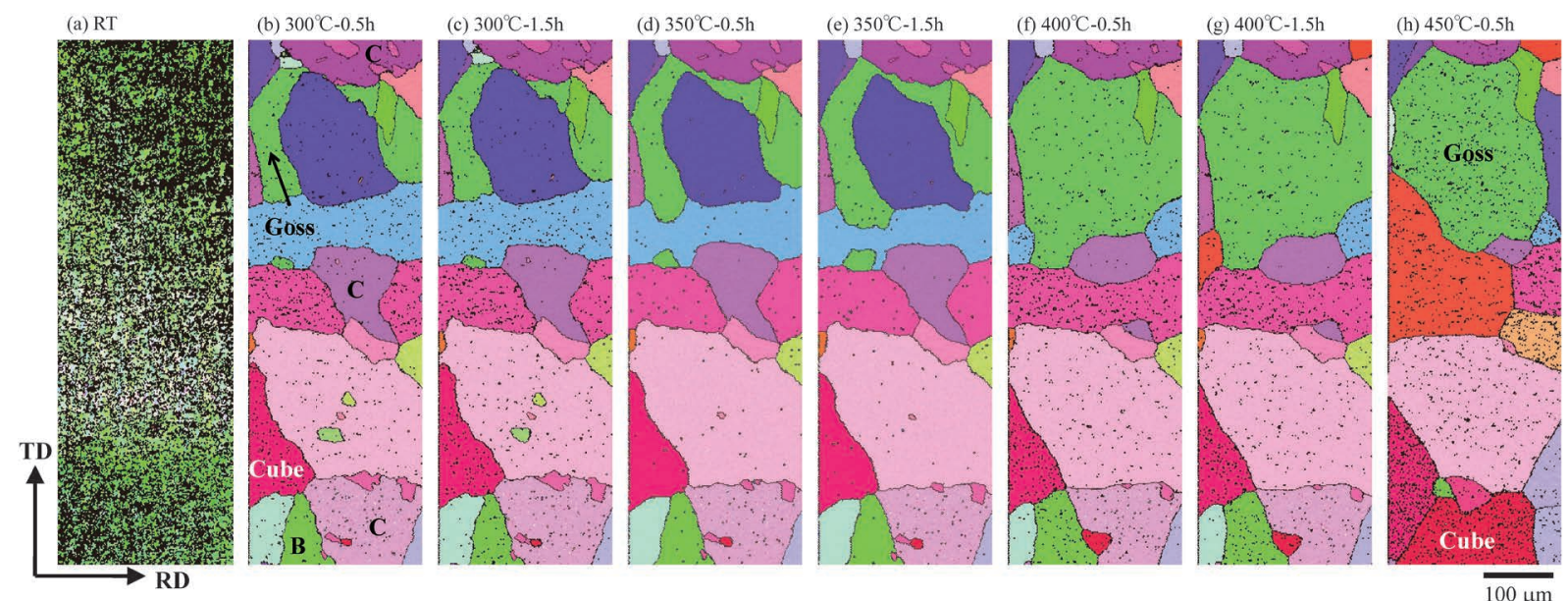

Fig. 11 ND plane crystal orientation distribution maps of cold rolled sheets of Alloy B by using in-situ heating EBSD analysis.

成分の存在状態を確認した結果，A合金ではこれらに属さな い結晶粒が成長するのに対して, B 合金ではその挙動はまっ たく異なっていた。すなわち, $350^{\circ} \mathrm{C}$ の熱処理までは, Brass 方位 $(\{110\}\langle 112\rangle)$ と Copper方位 $(\{112\}\langle 111\rangle)$ の圧延集 合組織成分をもつ再結晶粒が成長しているが, $400^{\circ} \mathrm{C}$ 以降で は, 熱処理初期から存在していたCube方位 $(\{100\}\langle 001\rangle)$ とGoss方位（\{110\}〈001〉）が周りの粒を虫食して成長して いることが明らかになった。

以上の結果より, $\mathrm{Al}_{3}(\mathrm{Sc}, \mathrm{Zr})$ 粒子が存在することによっ て, Al- $\mathrm{Mg}-\mathrm{Si}$ 合金の再結晶挙動は大きく変化し, 一次再結 晶終了後の結晶粒形状を $450^{\circ} \mathrm{C}$ までは維持することが明らか になった。また,この観察結果より, $\mathrm{Al}_{3}(\mathrm{Sc}, \mathrm{Zr})$ 粒子は一 次再結晶後の粒成長の抵抗だけでなく, 一次再結晶開始温度 の高温化，すなわち回復過程に影響を及ぼていることが明 らかになった。 $\mathrm{Al}-\mathrm{Mg}-\mathrm{Si}$ 合金に扔いて, $\mathrm{Mg}-\mathrm{Si}$ 系化合物や $\mathrm{Si}$ 相の存在を無視することはできない。 $\mathrm{Al}_{3}(\mathrm{Sc}, \mathrm{Zr})$ 粒子は $500^{\circ} \mathrm{C}, 600^{\circ} \mathrm{C}$ の温度保持に扔いても平均粒子径が $100 \mathrm{~nm}$ 以下 の粒子として存在することからも熱的に安定な粒子であるた め, $\mathrm{Mg}-\mathrm{Si}$ 化合物等よりも結晶粒組織の制御に有効であると 考えられる。組織制御の可能性や時効硬化挙動や引張変形挙 動の評価など，さらなる検討が必要ではあるが，熱的に安定
な $\mathrm{Al}_{3}(\mathrm{Sc}, \mathrm{Zr})$ 粒子は, 特別な加工熱処理工程を施さなくて も集合組織のランダム化や結晶粒微細化に寄与することが示 され，これらの組織変化が $\mathrm{Al}-\mathrm{Mg}-\mathrm{Si}$ 合金の成形性㧤よび強 度の向上に寄与することが期待される。

\section{4. 結言}

Al-Mg-Si 合金の再結晶挙動に及ぼす $\mathrm{Sc} と \mathrm{Zr}$ の影響を明ら かにするために, ScとZrを微量添加した合金を作製し，第 二相粒子の存在状態や再結晶粒成長挙動について調查した結 果，以下のことが明らかになった。

（1） Sc，Zr を複合添加した熱間圧延試料は，無添加合金 よりも結晶粒が微細化し, 結晶粒内の第二相粒子には母相 と半整合と非整合関係にある 2 種類の球状 $\mathrm{Al}_{3}(\mathrm{Sc}, \mathrm{Zr})$ 粒子, 棒状 $\mathrm{Al}_{3}(\mathrm{Sc}, \mathrm{Zr})$ 粒子小よび棒状 $\mathrm{Si}$ 粒子が存在することが明 らかになった。棒状 $\mathrm{Al}_{3}(\mathrm{Sc}, \mathrm{Zr})$ 粒子は鋳造時の晶出, 半整 合の球状 $\mathrm{Al}_{3}(\mathrm{Sc}, \mathrm{Zr})$ 粒子は均質化処理時の析出, 非整合の 球状 $\mathrm{Al}_{3}(\mathrm{Sc}, \mathrm{Zr})$ 粒子は棒状粒子が熱間圧延で分断すること で生成したと考えられる。

（2）複合添加合金冷間圧延試料に焼なまし処理を行った

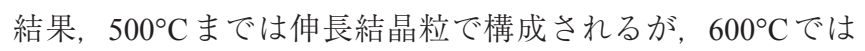
等軸化することが明らかになった。一方, 無添加合金冷間圧 


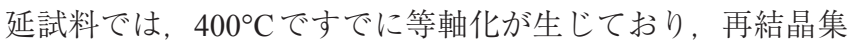
合組織成分を持つ結晶粒が多く占めていた。

（3）観察結果をもとに冷間圧延による蓄積ひずみエネ ルギーによる一次再結晶の駆動力, $\mathrm{Al}_{3}(\mathrm{Sc}, \mathrm{Zr})$ 粒子による Zener force および再結晶粒径による粒成長の駆動力を評価し た結果, $\mathrm{Al}_{3}(\mathrm{Sc}, \mathrm{Zr})$ 粒子は, 一次再結晶後の粒成長の抵抗 となることが予測された。

(4) $300 \sim 450^{\circ} \mathrm{C}$ における再結晶粒成長過程を明らかにす るために, その場加熱 SEM/EBSD解析を行った結果, 複合 添加合金では再結晶開始温度が高温化すること, 一次再結晶 粒の粒成長が抑制されることが明らかになった。一方，無添 加合金では $300^{\circ} \mathrm{C}$ の段階で一次再結晶がほぼ終了しているこ と, 圧延集合組織成分および再結晶集合組織成分が優先成長 することが確認された。

（5） $\mathrm{Al}_{3}(\mathrm{Sc}, \mathrm{Zr})$ 粒子は, 特別な加工熱処理を施すことな く, $\mathrm{Al}-\mathrm{Mg}-\mathrm{Si}$ 合金の集合組織のランダム化や結晶粒微細化 が期待できることから, 組織制御による材料特性向上へ有効 な粒子であることがわかった。

謝 辞

本研究の試料作製に際し，株式会社神戸製鋼所真岡製造所 および九州大学の西畑義則氏，横手達夫氏にご協力いただき ました。深く感謝申し上げます。なお，本研究の一部は，一 般社団法人日本アルミニウム協会「アルミニウム研究助成事 業」, 公益財団法人軽金属奨学会「研究補助金」の支援, な らびにJSPS 科研費 $16 \mathrm{H} 04502$ にり行われました。ここに特 記して感謝の意を表します。

\section{参 考 文 献}

1）たとえば，櫻井健夫：神戸製鋼技報，57（2007），45-50.

2) 瀬戸一洋：自動車の軽量化テクノロジー, NTS, (2014), 23-30,

3) J. Røyset and N. Ryum: Int. Mater. Rev., 50 (2005), 19-44.

4) 藤川辰一郎：軽金属, 49 (1999), 128-144.

5）岩村信吾, 美浦康宏：軽金属, 56（2006），100-104.

6) A. Tolley, V. Radmilovic and U. Dahmen: Scr. Mater., 52 (2005), $621-625$.

7) C. B. Fuller, J. L. Murray and D. N. Seidman: Acta Mater., 53 (2005), 5401-5413.

8) V. Radmilovic, A. Tolley, E. A. Marquis, M. D. Rossell, Z. Lee and U. Dahmen: Scr. Mater., 58 (2008), 529-532.

9) B. Forbord, H. Hallem, J. Røyset and K. Marthinsen: Mater. Sci. Eng. A, 475 (2008), 241-248.

10）池田賢一, 宮田幸昌, 吉原隆浩, 高田尚記, 中島英治：軽金属, 64 (2014), 353-360.

11) S. Iwamura and Y. Miura: Acta Mater., 52 (2004), 591-600.

12) A. F. Norman, P. B. Prangnell and R. S. McEwen: Acta Mater., 46 (1998), 5715-5732.

13) C. B. Fuller, A. R. Krause, D. C. Dunand and D. N. Seidman: Mater. Sci. Eng. A, 338 (2002), 8-16.

14) K. Ikeda, R. Akiyoshi, T. Takashita, M. Mitsuhara, S. Hata, H. Nakashima, K. Yamada and K. Kaneko: Proc. of $13^{\text {th }}$ International Conference on Aluminum Alloys (ICAA13), (2012), 1181-1185.

15) M. J. Jones and F. J. Humphreys: Acta Mater., 51 (2003), 2149-2159.

16) W. T. Read and W. Shockley: Phys. Rev., 78 (1950), 275-289.

17) W. T. Read: Dislocation in Crystals, McGraw Hill, (1953).

18) F. J. Humphreys and M. Hatherly: Recrystallization and Related Annealing Phenomena, Second Edition, Elsevier, (2004).

19) E. Nes, N. Ryum and O. Hunderi: Acta Metall., 33 (1985), 11-22. 